ACTA THERIOLOGICA

Vol. 24, 2: 23-34, 1979

\title{
Quality Evaluation of Roe-deer Antlers from an Industrial Region in Southern Poland ${ }^{1}$
}

\author{
Krzysztof JOP
}

\begin{abstract}
Jop K., 1979: Quality evaluation of roe-deer antlers from an industrial region in Southern Poland. Acta theriol., 24, 2: 23-34 (With 4 Tables \& 3 Figs.)

Examination was made of 357 roe-deer (Capreolus capreolus Linnaeus, 1758) antlers obtained in the Niepolomice Forest $\left(50^{\circ} 07^{\prime} \mathrm{N}\right.$, $20^{\circ} 23^{\prime} \mathrm{E}$ ) during the period $1920-1973$, analyzing the weight of the antlers, length of the two branches, volume of the antlers as a whole and their quality (general evaluation in accordance with CIC international tables). The quality of antlers was found to have deteriorated drastically as from the late fifties. The weight of antlers had decreased on an average from 244 to $166 \mathrm{~g}(32 \%)$, length of branches by $29 \%$ and general evaluation of antlers by $23-30 \%$. Deterioration in the value of roe-deer antlers took place 2-3 years after the very large steel and iron works in the immediate vicinity of the Niepolomice Forest had begun operating. A discussion of possible causes of the phenomenon described is given in this paper.

[Dept. Animal Ecology, Jagiellonian Univ., Krupnicza 50, 30-060 Kraków, Poland].
\end{abstract}

\section{INTRODUCTION}

The Niepolomice Forest is formed by a large complex of lowland treestands $\left(11,000\right.$ ha $\left.-50^{\circ} 07^{\prime} \mathrm{N}, 20^{\circ} 25^{\prime} \mathrm{E}\right)$ which have been subjected to pressure from the rapidly spreading urban an industrial agglomeration of Kraków (Grodziński, 1976). It consists of pine woods and to a lesser degree of deciduous forests (M y c z kow ski \& Lesiński, 1976; Denisiuk \& Medwecka-Kornaś, 1977). During the last twenty years these treestands have come within the zone of serious industrial gas and dust pollution ( $\mathrm{Czerwieniec}$, 1976).

The treestands of the Niepolomice Forest were previously known for the high quality of the game animals living there. The present numbers of deer there are about 1300 roe-deer and 180 red deer $(\mathrm{P} \mathrm{u}$ c e $\mathrm{k}$ et al., 1975) Although the current state of roe-deer in the Niepolomice Forest is very good, the quality of their antlers has, as both hunters and foresters agree, greatly deteriorated. This has been

\footnotetext{
${ }^{1}$ Study carried out under project 10.2.07.02.02
} 
attributed to the effects of industrial pollution from the nearby iron and steel works (G rodzińs ka, 1977).

The purpose of this study was to establish to what degree the opinions of those practically connected with hunting and shooting activities are correct, and consequently analysis has been made of the quality of roe-deer antlers obtained in the Niepolomice Forest during the last fifty years.

\section{MATERIAL AND METHODS}

The material used for this study consisted of 357 roe-deer antlers, the animals having been shot in the Niepołomice Forest during the period from 1920-1973. The antlers were examined in private collections of sportsmen and employees of the State Forests and were also based on the annual evaluations made in the District State Forest Board in Cracow between 1971-1973. No damaged antlers or antlers which did not possess accurate records (year and place of shooting) were taken into consideration.

Evaluation of all antlers was made in accordance with the tables of Conseil International de la Chasse (Sikorski, 1969; Pielowski, 1970). The antlers were weighed with acouracy to 1 gramme. $10 \%$ of their weight was deducted in the case of antlers obtained during the last three years to allow for drying. A water bath was used to measure volume, length of branches was measured with a steel tape measure with accuracy to $1 \mathrm{~mm}$. Results of measurements were entered in evaluation tables. Quality of antlers was defined by totalling the number of points obtained from all measurements and evaluation of the beauty of the antlers.

\section{RESULTS}

The whole antler material used for the studies was divided into three groups $(A, B, C)$, which respectively were obtained during the periods from $1920-56,1957-1966$ and $1967-73$ (Table 1). The division into these periods was dictated by the start of operations in the Lenin Iron and Steel Works and their further development. Group $A$ can form a point of reference for the two subsequent groups, since up to the fifties of this century industrial gas and dust pollution in the Niepolomice Forest region was negligible. Group $B$ represents the years of intensive initial operation of the main department of the iron and steel works. Group $C(1967-1973)$ is the period of complex development of the works and great intensification of its production.

The initial inspection of data (Table 2) points to the dramatic deterioration in the quality of roe-deer antlers, particularly during the second period, i.e. from 1957-1966. This applies to practically all of the characteristics examined and exerted a very distinct influence on the award of points in evaluating antlers. Comparison began with comparing qualitative differences between periods $A$ and $B$ and $C$ 
Table 1

Material consisting of roe-deer antlers (N) from the Niepolomice Forest arranged in order of year when obtained, with division into three periods: $A$ (1920-1956), B (1957-1966), C (1967-1973).

\begin{tabular}{rrrr}
\hline Period/Year & N & Period/Year & N \\
\hline A 1920 & 1 & $B$ & 1957 \\
1936 & 1 & 1958 & 5 \\
1937 & 1 & 1959 & 8 \\
1938 & 2 & 1960 & 10 \\
1941 & 1 & 1961 & 12 \\
1945 & 2 & 1962 & 10 \\
1947 & 2 & 1963 & 12 \\
1948 & 3 & 1964 & 13 \\
1949 & 5 & 1965 & 10 \\
1950 & 5 & 1966 & 14 \\
1951 & 4 & Subtotal & 104 \\
1952 & 4 & 1967 & 20 \\
1953 & 7 & 1968 & 24 \\
1954 & 5 & 1969 & 20 \\
1955 & 3 & 1970 & 21 \\
1956 & 6 & 1972 & 50 \\
Subtotal & 52 & 1973 & 38 \\
& & Subtotal & 201 \\
& & Total & 357 \\
& & &
\end{tabular}

Table 2

Characteristics of roe-deer antlers from the Niepolomice Forest in three periods: A $(1920-1956), B(1957-1966), C$ (1967-1973). Averages $(\overline{\mathrm{x}})$, standard deviations (S.D.) and coefficients of variation (C.V.) in percentages given for all characteristics.

\begin{tabular}{rlrrrrrr}
\hline Period & & $\begin{array}{c}\text { CIC } \\
\text { points }\end{array}$ & $\begin{array}{c}\text { Left } \\
\text { branch } \\
(\mathrm{cm})\end{array}$ & $\begin{array}{c}\text { Right } \\
\text { branch } \\
(\mathrm{cm})\end{array}$ & $\begin{array}{c}\text { Average } \\
\text { length } \\
\text { of } \\
\text { branches } \\
(\mathrm{cm})\end{array}$ & $\begin{array}{c}\text { Volume } \\
\left(\mathrm{cm}^{8}\right)\end{array}$ & $\begin{array}{c}\text { Weight } \\
(\mathrm{g})\end{array}$ \\
\hline \multirow{2}{*}{$A$} & $\overline{\mathrm{x}}$ & 88.92 & 20.82 & 21.71 & 21.10 & 88.92 & 243.80 \\
& SD & 17.92 & 3.39 & 3.15 & 3.91 & 40.42 & 40.82 \\
& CV & 21.49 & 17.33 & 16.29 & 20.10 & 37.12 & 15.66 \\
$B$ & $\overline{\mathrm{x}}$ & 61.73 & 15.27 & 16.64 & 14.95 & 62.85 & 166.39 \\
& SD & 21.0 & 5.0 & 4.61 & 5.33 & 31.82 & 62.79 \\
& CV & 35.16 & 33.25 & 30.18 & 36.61 & 50.47 & 38.07 \\
C & $\bar{x}$ & 66.46 & 15.37 & 15.03 & 14.93 & 84.09 & 166.48 \\
& SD & 52.93 & 5.38 & 5.43 & 5.56 & 41.27 & 76.68 \\
& CV & 39.10 & 34.83 & 36.08 & 37.30 & 46.18 & 46.20 \\
\hline
\end{tabular}

(Table 3). In relation to the initial period $(A)$ the two subsequent periods $(B, C)$ differ considerably in respect of all the characteristics examined. It is particularly in respect of weight and length of the two branches that differences are very great between the periods compared, being as much as an average of $30 \% \quad(28.7-31.7 \%)$, while the remaining 
Table 3

Differences in measurement characteristics and evaluation of roe-deer antlers from the Niepolomice Forest between period $A(1920-1956)$ and $B(1957-1966)$ and period $A$ and $C$ (1967-1973).

\begin{tabular}{lcccc}
\hline Characteristics & $\begin{array}{c}\text { Differences in values } \begin{array}{c}A-B \\
\text { absolute }\end{array} \\
\text { in } \%\end{array}$ & \multicolumn{2}{c}{$\begin{array}{c}\text { Differences in values } A-C \\
\text { absolute }\end{array}$} & in \% \\
\hline Weight & $-77.41 \mathrm{~g}$ & 31.7 & $-77.32 \mathrm{~g}$ & 31.7 \\
Volume & $-26.07 \mathrm{~cm}^{8}$ & 29.3 & $-4.83 \mathrm{~cm}^{3}$ & 5.4 \\
Avg. length of branches & $-6.15 \mathrm{~cm}$ & 29.1 & $-6.07 \mathrm{~cm}$ & 28.7 \\
Right branch & $-5.07 \mathrm{~cm}$ & 23.3 & $-6.07 \mathrm{~cm}$ & 27.8 \\
Left branch & $-5.55 \mathrm{~cm}$ & 24.7 & $-4.83 \mathrm{~cm}$ & 23.1 \\
CIC points & -26.36 & 29.9 & -21.63 & 24.5 \\
\hline
\end{tabular}

characteristics had deteriorated by an average of $25 \%$. The probability that all characteristic failed to differ between period groups $A, B$ and $C$ is less than $1 \%$, when tested by the chi-square test.

Having proved differences in material from the time aspect, the $t$-Student test was used to continue examining significance of differences between all characteristics in three consecutive periods (Table 4).

\section{Table 4}

Estimate of significance of differences for six characteristics of roedeer antlers from the Niepolomice Forest between successive periods $A$ (1920-56), $B(1957-66)$ and $C(1967-73)$, calculated by means of the $t-$ Student test: $+++=p<0.001 ;++=p<0.01 ;+=p \leqslant 0.05$.

\begin{tabular}{cccc}
\hline Average length of branches/Weight & $A$ & $B$ & $C$ \\
\hline$A$ & +++ & +++ & +++ \\
C & +++ & - & - \\
Volume/CIC points & $A$ & $B$ & $C$ \\
$A$ & & +++ & - \\
$B$ & +++ & +++ & ++ \\
$C$ & +++ & ++ & $C$ \\
Right branch/Left branch & $A$ & $B$ & +++ \\
$A$ & & +++ & +++ \\
$B$ & +++ & ++ & \\
\hline
\end{tabular}

Antlers from $1920-56(A)$ differed from antlers from $1957-66(B)$ to a highly significant degree $(p<0.001)$ in respect of all six characteristic examined. Similarly antlers from the two extreme periods, i.e. from $1920-56(A)$ and $1967-73(C)$ differed highly significantly $(p<0.001)$ in respect of all characteristics except volume of antlers.

Lesser differences in quality of antlers were found between the two 
later periods, i.e. $1957-66$ and $1967-73$ (cf. also Table 3). There are no significant differences between these periods in respect of the two most important characteristics, i.e. weight and average length of the branches of the antlers. If the length of right and left branch is examined separately, then for the right branch there is a highly significant difference between period $B$ and $C$, although both these characteristics have slightly improved recently (period $C$ ).

In order exactly to define the dynamics of deterioration in antlers the characteristics examined were analyzed in consecutive years (Fig. $1-2)$. The weight of antlers and general evaluation based on CIC points revealed fluctuations in different periods (Fig. 1). The value of these indexes can, however, easily be divided into two levels, between

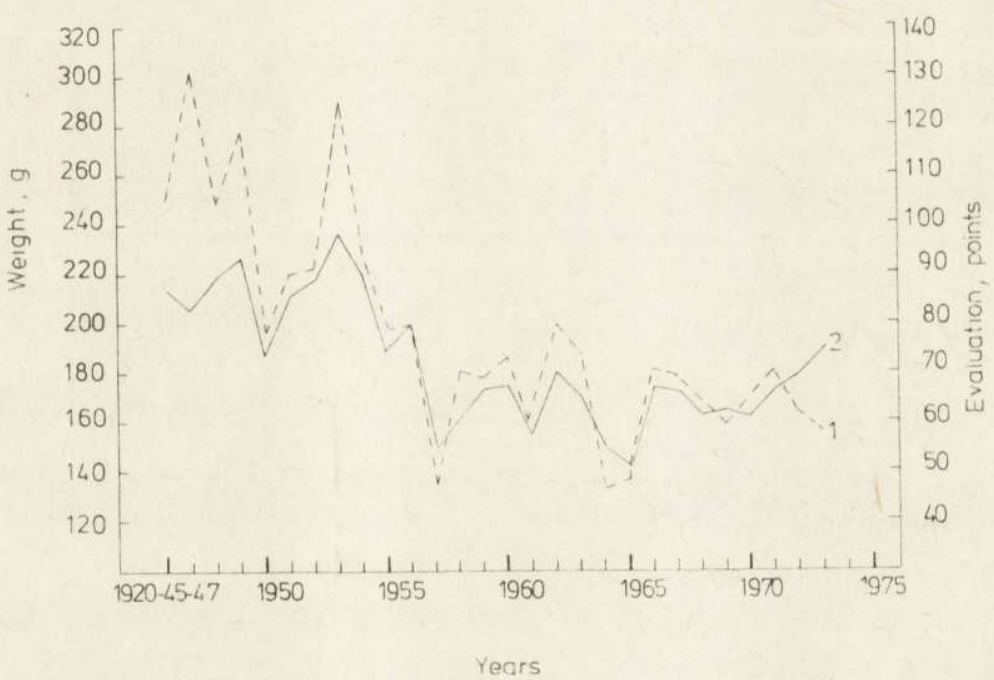

Fig. 1. Variations in weight and general value of roe-deer antlers from the Niepolomice Forest in years (1920) 1947-73. (Number of antlers examined - cf. Table 1) 1 - weight of antlers in grammes, 2 - evaluation of antlers according to CIC points.

which there is the interval representing 1956-57. Average weights for the first level varied from 220 to 300 grammes, whereas the second level is formed by values within limits from 130 to 200 grammes. The analogical values for evaluation on CIC points with the first, higher level, fluctuated from 75 to 100 , but at the next level from 50 to practically 70 grammes. The length of the right and left branch of roe-deer antlers exhibits considerable agreement, and consequently they have been given a joint diagram, together with the average value for both branches (Fig. 2). Here also it is possible to distinguish two levels of values, despite the considerable fluctuations in different years. Antlers of larger 
dimensions $(18-23 \mathrm{~cm})$ predominated up to 1956 , being followed by a decided decrease in their length to about $13-16 \mathrm{~cm}$. The volume of the antlers is the one characteristic which was not deteriorated so consistently as all the other foregoing characteristics (Fig. 3). The antlers from 1945 - 1955 had decidedly greater volume that those of subsequent years from 1957 to 1970. In the last three years (1971-1973) there has, however, been some degree of increase in the volume of antlers. Since this has not run parallel to increase in the weight of antlers (cf. Fig. 1-2), it may be assumed that at least in some of the antlers there had been a change in density (i.e. specific gravity).

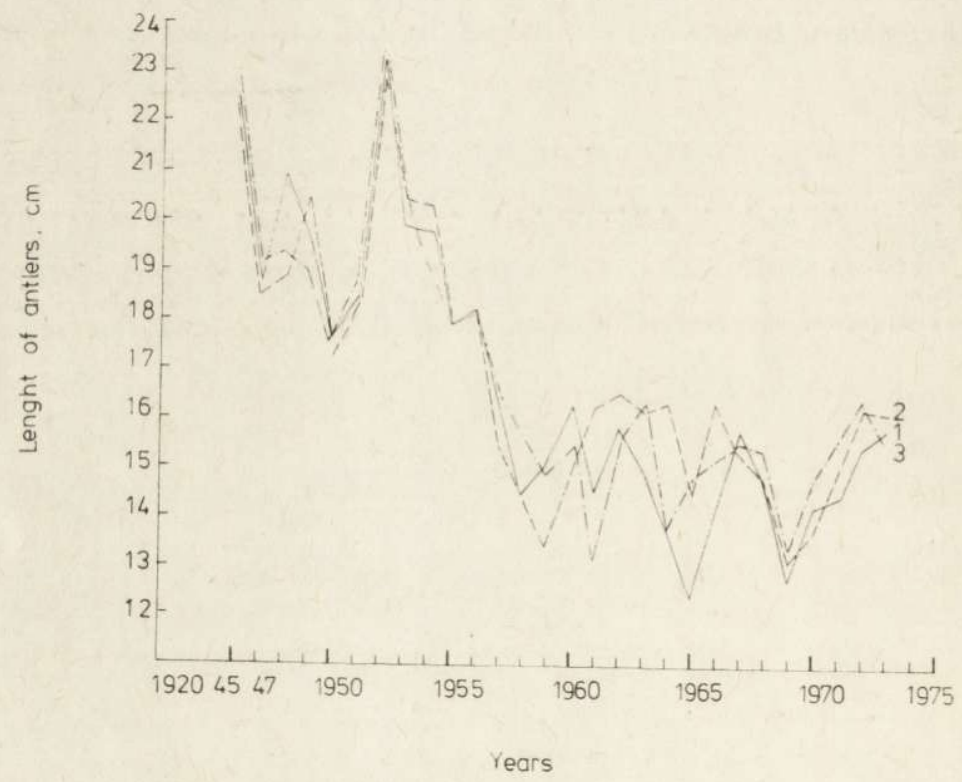

Fig. 2. Length (in $\mathrm{cm}$ ) of roe-deer antlers from the Niepolomice Forest in successive years (1920) 1947-73.

1 - average length of branches, 2 - right branch, 3 - left branch

The range of variation in antlers also increased in the study population. There were many poor antlers in addition to a certain number of average antlers, but only a few massive ones. This considerable variation is elearly reflected in the hight values of standard deviations, particularly the coefficient of variation (CV) (Table 2). The values of this coefficient were lowest in group $(A)$ for 1920 - 56, the average for all characteristics being then $21.33 \%$. In later periods, however, that is $B$ (1957-1966), and $C$ (1967-73), it increased on an average to $37.29 \%$. The greatest degree of variation is exhibited by weight and volume of antlers. Despite the fact that material from group $A$ was less numerous 
than in the subsequent groups $B$ and $C$, the coefficient of variation of almost all characteristics was about twice lower in the first period $(1920-1956)$ than in the two subsequent periods $(1957-66-73)$. This is irrefutable evidence of the fact that during the first period roe-deer antlers from the Niepolomice Forest were not only better in respect of the characteristics examined, but also less variable in their high quality.

\section{DISCUSSION}

The drastic deterioration in the quality of roe-deer antlers which has taken place over the fifties of this century in the roe-deer population in the Niepolomice Forest, is presented and documented in this paper.

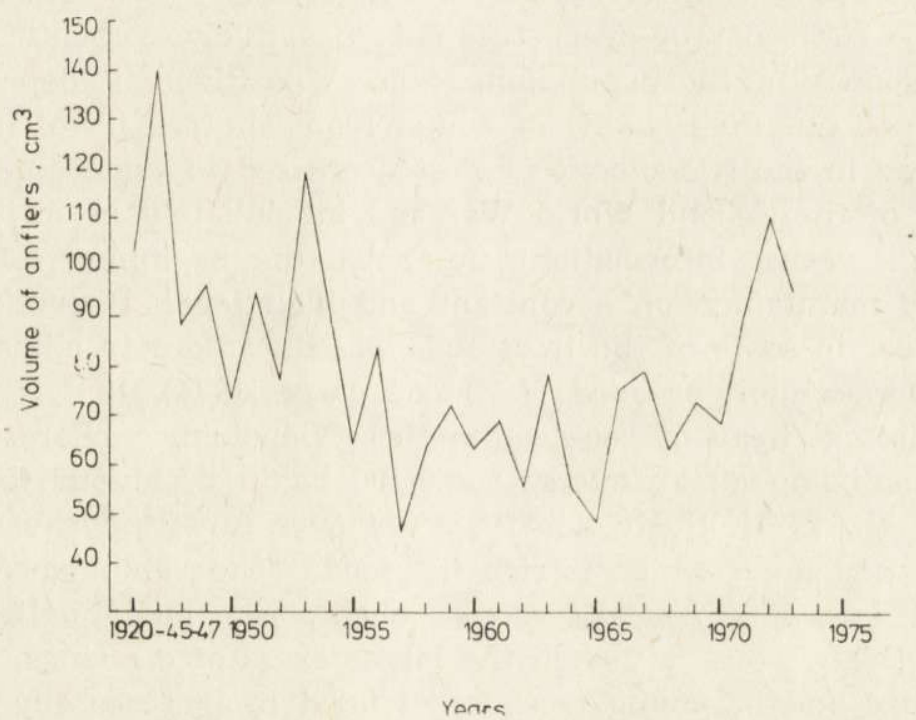

Fig. 3. Volume of roe-deer antlers (in $\mathrm{cm}^{3}$ ) from the Niepolomice Forest in successive years (1920) 1947-73

In theory at least three causes can be considered for this phenomenon, connecting it with (1) genetic isolation and overcrowding of the roedeer population, (2) selective management in the shooting area, and (3) contamination of the forest habitat itself.

\section{Genetic Isolation}

The roe-deer population currently living in the Niepolomice Forest numbers about 1300 animals, 1000 of which live in coniferous treestands and over 300 in deciduous tree stands ( $\mathrm{Pucek}$ et al., 1975). There is both migration and constant passage of roe-deer between all the tree 
stands forming the Forest. The Niepolomice population has also considerable contact with roe-deer from the neighbouring forests of the neighbouring forests of the Carpathian foothills. It is therefore a large population, not threatened by isolation or closing of the gene pool. With the fights between males during the rutting season and the matings taking place under this system there can be no question of a high degree of inbreeding in the study population of roe-deer. It is thus very unlikely that the extreme polygenic characteristics, for such poor antlers are considered to be, could dominate in the whole population within a short time (M a y r, 1963).

It is a known fact from hunting practice that the size of roe-deer and quality of their antlers deteriorate in greatly overcrowded shooting areas (Pasławski, 1971). Bobek (1977) is of the opinion that the average weight of roe-deer antlers is negatively correlated with the winter density of the population, whereas positively it depends on the amount and nutritive quality of winter food. The density of the roe-deer population in the Niepolomice Forest decreased to some extent towards the end of the Second World War and immediately after it ( J. Rojkowski, verbal information), but since the beginning of the fifties has been maintained on a constant and high level. Reduction in head of roe-deer in some of the treestands was due more to climatic factors, such severe winters or floods (B o b e k et. al., 1974).

The present head of roe-deer in the Niepolomice Forest is fairly numerous, being on an average 13.0/100 ha in deciduous forests ( $\mathrm{P} \mathrm{u}$ c e k et al., 1975). Such density is however far from the capacity of this shooting area, which is rich in food. The abundance of food available in winter has also most probably remained unaltered during the last thirty years, although the larger areas of clearings, plantations of saplings and of young trees has tended to increase the amount of summer and not winter food. Thus the density itself of the population is unlikely to have become the cause of deterioration in roe-deer antlers.

\section{Selective Management}

Hunting management in respect of deer was based all over Poland on selective principles in the fifties. The Niepolomice Forest constituted an area coming under direct control of the Forest Administration of Cracow and hence selective shooting was introduced there earlier, for practical purposes directly after the Second World War. The quality of roe-deer antlers in the Niepolomice Forest did not decline to any great extent until $1956-60$, i.e. about 10 years after the introduction if selective management. The principles of selection for shooting are 
exactly the same for the whole of Poland (Pielowski, 1970; Pó 1 tor e cki, 1974). With implementation of this management the quality of roe-deer antlers has markedly improved in the majority of Polish voivodships ( $\mathrm{Pas}$ awski, 1971) whereas in the Niepolomice Forest the quality of antlers has deteriorated dramatically during the same period. It is thus impossible to connect the decline in the quality of roe-deer antlers in this area with faulty selective management.

\section{Contamination of the Forest Habitat}

Contamination of this forest ecosystem is very intense and has taken place chiefly as the result of industrial gas and dust pollution from the Lenin Iron and Steel Works (Grodziński, 1976). There is a very close coincidence in time between the course of development of the works and deterioration in roe-deer antlers (cf. Fig. 2 and 3). This took place within $2-3$ years after the three main sections of the works had begun operation (Biuletyn HiL. 1970). This is exactly the time required for development and attainment of maturity by young roe-deer. It would thus appear that the first attack of industrial pollution on the tree stands of the Niepolomice Forest affected the quality of roe-deer antlers, which have remained on a poorer level since the end of the fifties.

The Cracow region is characterized by the greatest metallurgical pollution in Poland and one of the greatest degrees of sulphur oxide pollution, if calculated per $\mathrm{km}^{2}$ of area ${ }^{2}$. The yearly fall of dust on the deciduous and coniferous treestands of the Niepolomice Forest from 1970-72 reached a level of $80-45 \mathrm{t} / \mathrm{km}^{2}$, while the contents of iron alone in this fall was from $300-800 \mathrm{~kg} / \mathrm{km}^{2}$ ( $\mathrm{R} \mathrm{a} \mathrm{pacz} \mathrm{\&} \mathrm{Bartosik,}$ 1976). Concentration of $\mathrm{SO}_{2}$ measured in the treestands of the Niepolomice Forest from 1967-69 was highest during the winter months (Ka sina, 1971; Morawska-Hor awska, 1971). Local climate conditions in the Cracow conurbation (winds, precipitation and fogs) favour the spread of industrial gases and dusts in an eastern direction. Over the yearly cycle in the Cracow district western and south-western winds predominate, and the annual number of days with precipitation is as much as 170 ( $\mathrm{Hes} \mathrm{s}, 1974)$. In addition there are many foggy or misty days in the Vistula valley and the lowland areas of the Niepolomice Forest.

The Niepolomice Forest functions in this region as an active absorber of industrial pollution, accumulating a considerable concentration in biological material of sulphur compounds ( $\mathrm{Ka} \mathrm{r} \mathrm{kan} \mathrm{i} \mathrm{s,} \mathrm{1976)} \mathrm{and} \mathrm{heavy}$

${ }^{2}$ Statistical Yearbook. Central Statistics Office, Warsaw 1976, pp. 16 and 50. 
metals ( $\mathrm{Makomaska}$, 1977). All this has resulted in serious contamination of the forest habitat of the Niepolomice Forest, in particular:

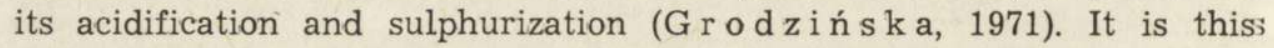
food which the roe-deer feed on mainly in winter and early spring,, when their antlers form (B o be k et. al., 1972). High contents of toxic: heavy metals such as lead, zinc and cadmium have been found in the antlers of roe-deer from the Niepolomice Forest (S a wi cka-Ka p u -$\mathrm{sta}, 1977)$. Although we do not as yet understand the physiological background of this phenomenon, it would appear probable that the intensively contaminated winter food of roe-deer exerts an unfavourable effect on the development of their antlers. Data on the quality of roedeer antlers from other industrial areas, e.g. in Czechoslovakia ( $\mathrm{N} \mathrm{o-}$ vakova \& Hanzl, 1965) show some degree of agreement with the observations presented in this paper, although they may be differently interpreted.

Of the three causes discussed here of the marked deterioration in the antlers of roe-deer in the Niepolomice Forest, the most likely would appear to be the third possibility discussed, i.e. the serious contamination of the forest habitat itself.

Acknowledgements: I am very grateful to Professor Dr. W. Grodziński for his personal guidance during these studies and for his patient examination of the manuscript.

\section{REFERENCES}

1. Bobek B., 1977: Strategies of roe-deer management in various forest ecosystems. Proc. XIIIth Inter. Congr. Game Biologists, Atlanta (in press).

2. Bobek B., Drożdż A., Grodziński W. \& Weiner J., 1974: Studies on productivity of the roe-deer population in Poland. Proc. XIth Inter. Congr. Game Biologists: 115-123. Stockholm 1973.

3. Bobek B., Weiner J. \& Zieliński J., 1972: Food supply and its consumption by deer in deciduous forest of Southern Poland. Acta theriol., 17, 15: $187-202$.

4. Czerwieniec M., 1976: Wstępna ocena zagrożenia lasów przez zanieczyszczenia atmosfery $w$ regionie krakowskim. Biuletyn IKS, 11-12: 23-27.

5. Denisiuk Z. \& Medwecka-Kornaś A., 1977: Distribution of the plant communities and the potential natural vegetation in the northern part of the Niepolomicka Forest. Studia Naturae, A., 13: 171-195.

6. Grodzińska K., 1977: Changes in the forest environment in Southern Poland as a result of steel mill emissions. [In: „Vegetation science and environmental protection«. Eds Miyawaki A. \& Tüxen R.]. 207-215. Maruzen Co. Ltd., Tokyo.

7. Grodzińska K., 1971: Acidification of tree bark as a measure of air pollution in Southern Poland. Bull. Acad. Pol. Sci., Cl. II., 19, 3: 189-195.

8. Grodziński W., 1976: Ecological consequences of industrial impact upon 
forest ecosystems as exemplified by the Niepolomice Forest (S. Poland)., Regional Meeting MAB, Brno, Czechoslovakia 1-9 pp.

9. Hess M., 1974: The climate of the Cracow aglomeration. Zesz. Nauk. AGH, Sozol. i Sozotechn., 1: 79-93.

10. Karkanis M., 1976: The circulation of sulphur in the forest ecosystem Tilio-Carpinetum in the northern part of Puszcza Niepolomicka near Ispina. Fragm. Flor. Geobat., 22, 3: 351-363.

11. Kasina S., 1971: Rozkład zanieczyszczeń atmosferycznych w rejonie Puszczy Niepolomickiej. Ochr. Powietrza, 5, 5: 5-8.

12. M a k oma k a M., 1977: Ocena skażeń metalami ciężkimi wybranych kompleksów leśnych w Sląsko-Krakowskim Okręgu Przemysłowym. Ph.D. Thesis, Jagiellonian Univ. Kraków, 62 pp.

13. May r E., 1963: Animal species and evolution. Belknap Press of Harvard Univ. Press: 1-797. Cambridge, Mass.

14. Morawska-Horawska M., 1971: Wpływ warunków atmosferycznych na rozchodzenie się dwutlenku siarki w Krakowie i okolicy. Folia Geogr., Geogr.-Physica, 5: 45-62.

15. Myczkowski S. \& Lesiński J.A., 1976: Ecosystems of Niepołomice forest as influenced by industrial fumes. XVI Congr. IUFRO Oslo 1976., 1-8.

16. Novakova E. \& Hanzl R., 1965: Zmeny $\mathrm{v}$ kvalite srncich parużku z podkmuśnohorskie prumyslove oblasti. Sbornik Vedeckeho Lesnickeho Ustavu, 8: $229-243$.

17. Pa sławski T., 1971: Rozważania nad jakością naszych sarn. Łowiec Polski, 9 (1396): 4-11.

18. Pielowski Z., 1970: Sarna. Państw. Wyd. Roln. Leśne: 1-219. Warszawa.

19. Półtoracki W., 1974: Jak selekcjonować sarny. Łowiec Polski, 6 (1465): $4-5$.

20. Pucek Z., Bobek B., Łabudzki L., Miłkowski L., Morow K. \& Tomek A., 1975: Estimates of density and number of ungulates. Pol. ecol. Stud., 1, 2: 121-135.

21. Rapacz J. \& Bartosik J., 1976: Rozprzestrzenianie się zanieczyszczeń atmosferycznych $w$ obszarach leśnych na przykładzie rejonu Huty im. Lenina i Puszczy Niepołomickiej. Biuletyn IKS., 9: 24-26.

22. Sawicka-Kapusta K., 1977: Heavy metal contents in the roe deer antlers from the Silesian Forests. Arch. Ochrony Srod. (in press).

23. Sikorski W., 1969: Ogólnopolska wystawa łowiecka 25-PRL. Katalog, Naczelna Rada Łowiecka, Warszawa.

24. XX-lecie Huty im. Lenina, 1970: Biuletyn wydany przez HiL.

Accepted, August 10, 1978.

Krzysztof JOP

\section{OCENA JAKOSCI POROŻA ROGACZY W LASACH REGIONU PRZEMYSEOWEGO POLSKI POEUDNIOWEJ}

Streszczenie

Zbadano 357 poroży sarn (Capreolus capreolus L.) pozyskanych w Puszczy Niepołomickiej w latach 1920-1973 (Tabela 1). Analizowano przy tym ciężar trofeów, 
długość obu tyk, objętość poroża oraz jego piękno (ocena ogólna wg międzynarodowych tabel CIC). Stwierdzono drastyczne pogorszenie się jakości poroży poczynając od późnych lat pięćdziesiątych (Tabela 2). Ciężar parostków obniżył się średnio z 244 do $166 \mathrm{~g}(32 \%)$ (Ryc. 1), długość tyk o 29\% (Ryc. 2) a także objętość (Ryc. 3), ogólna ocena trofeów o 25-30\% (Tabela 3). Pogorszenie się wartości poroży rogaczy nastapiło w $2-3$ lata po uruchomieniu $w$ bezpośrednim sąsiedztwie lasów Puszczy Niepołomickiej wielkiego kombinatu żelaza i stali. Przydyskutowano możliwe przyczyny opisanego zjawiska. 